\title{
Critical Period for Activity-Dependent Synapse Elimination in Developing Cerebellum
}

\author{
Sho Kakizawa,, ${ }^{1,2}$ Miwako Yamasaki, ${ }^{3}$ Masahiko Watanabe, ${ }^{3}$ and Masanobu Kano ${ }^{1,2}$ \\ ${ }^{1}$ Department of Physiology, Kanazawa University School of Medicine, Kanazawa 920-8640, Japan, ${ }^{2}$ Core Research for \\ Evolutional Science and Technology, Japan Science and Technology Corporation, Kawaguchi, Saitama 332-0012, Japan, \\ and ${ }^{3}$ Department of Anatomy, Hokkaido University School of Medicine, Sapporo 060-8638, Japan
}

Synapse elimination is considered to be the final step in neural circuit formation, by causing refinement of redundant connections formed at earlier developmental stages. The developmental loss of climbing fiber innervation from cerebellar Purkinje cells is an example of such synapse elimination. It has been suggested that NMDA receptors are involved in the elimination of climbing fiber synapses. In the present study, we probed the NMDA receptor-dependent period of climbing fiber synapse elimination by using daily intraperitoneal injections of the NMDA receptor antagonist MK-801. We found that blockade of NMDA receptors during postnatal day 15 (P15) and $\mathrm{P} 16$, but not before or after this period, resulted in a higher incidence of multiple climbing fiber innervation and caused a mild but persistent loss of motor coordination. Neither basic synaptic functions nor cerebellar morphology were affected by this manipulation. Chronic local application of MK-801 to the cerebellum during
P15 and P16 also yielded a higher incidence of multiple climbing fiber innervation. During P15-P16, large NMDA receptormediated EPSCs were detected at the mossy fiber-granule cell synapse, but not at the parallel fiber-Purkinje cell or climbing fiber-Purkinje cell synapse. It is therefore likely that the NMDA receptors located at the mossy fiber-granule cell synapse mediate signals leading to the elimination of surplus climbing fibers. These results suggest that an NMDA receptor-dependent phase of climbing fiber synapse elimination lasts $2 \mathrm{~d}$ at most. During this phase, the final refinement of climbing fiber synapses occurs, and disruption of this process leads to permanent impairment of cerebellar function.

Key words: climbing fiber; Purkinje cell; cerebellum; synapse elimination; development; critical period; NMDA receptor; MK801; activity-dependent
Proper function of the CNS requires precise formation of neural circuitry during development. Initially, synapses are immature in structure and function and are redundant in their connectivity. In subsequent developmental stages, synapses undergo activitydependent refinement such that supernumerary connections are eliminated and functionally important ones are strengthened (Changeux et al., 1973; Purves and Lichtman, 1980; Crépel, 1982; Katz and Shatz, 1996; Lohof et al., 1996; Nguyen and Lichtman, 1996). For example, formation of ocular dominance columns in the visual cortex (Chapman et al., 1986) and whisker-related patterns of connectivity in the somatosensory system ( $\mathrm{Li}$ et al., 1994; O’Leary et al., 1994; Kutsuwada et al., 1996; Iwasato et al., 1997) are considered to be dependent on neural activity. Such activity-dependent synapse refinement occurs during a restricted period of development called the critical period, which varies in duration and timing for different synapses (Gordon and Stryker, 1996; Vitalis et al., 1998; Toki et al., 1999).

The synapse between climbing fibers and Purkinje cells in the cerebellum provides a good model to study the cellular and molecular mechanisms that underlie synapse elimination in the

Received Dec. 21, 1999; revised April 17, 2000; accepted April 20, 2000.

This study has been partly supported by grants from The Japanese Ministry of Education, Science, Sports and Culture (M.W., M.K.) and Human Frontier Science Program (M.K.), and also by Special Coordination Funds for Promoting Science and Technology from Science and Technology Agency (M.W., M.K.). We thank Dr. Kazuyuki Imamura for providing Elvax polymer and Drs. T. Ohno-Shosaku, T. Tabata, K. Hashimoto, and G. J. Augustine for critically reading this manuscript.

Correspondence should be addressed to Masanobu Kano, Department of Physiology, Kanazawa University School of Medicine, 13-1 Takara-machi, Kanazawa 920-8640, Japan. E-mail: mkano@med.kanazawa-u.ac.jp.

Copyright () 2000 Society for Neuroscience $0270-6474 / 00 / 204954-08 \$ 15.00 / 0$ brain (Changeux et al., 1973; Crépel, 1982; Lohof et al., 1996). Climbing fibers originate from the inferior olive of the medulla and make strong excitatory synapses onto the proximal dendrites of Purkinje cells (Ito, 1984). In early postnatal days of a rodent's life, most Purkinje cells are innervated by multiple climbing fibers (Changeux et al., 1973; Crépel, 1982; Ito, 1984; Lohof et al., 1996). Elimination of supernumerary climbing fibers then occurs until each Purkinje cell is innervated by a single climbing fiber. This one-to-one relationship is attained by the end of the third postnatal week and is maintained throughout life (Changeux et al., 1973; Crépel, 1982; Ito, 1984; Lohof et al., 1996). A previous study showed that blockade of NMDA receptors impairs elimination of climbing fiber synapses in the rat (Rabacchi et al., 1992). However, the precise critical period for elimination of climbing fiber synapses has not been determined. Climbing fiber synapse elimination proceeds in parallel with other dynamic developmental events in the cerebellum, including granule cell migration, parallel fiber synapse formation, and Purkinje cell dendrite growth (Ito, 1984; Altman and Bayer, 1997), so that climbing fiber synapse elimination could include phases that do not require NMDA receptor-mediated neural activity. Thus, it is important to specify at which stage of cerebellar development and at which synapses in the cerebellum NMDA receptors are involved in the elimination of climbing fiber synapses.

We show here that blockade of NMDA receptors during postnatal day 15 (P15) to P16 is sufficient to prevent climbing fiber synapse elimination and that this treatment also causes impairment of motor coordination. NMDA receptor blockade did not change cerebellar morphology or the basic properties of synapses. 
These results suggest that climbing fiber synapse elimination requires NMDA receptors during this critical period and that disruption of synapse elimination leads to persistent impairment of cerebellar function.

\section{MATERIALS AND METHODS}

Application of $M K-801$. For experiments to probe the critical period for NMDA receptor-dependent synapse elimination, MK-801 $(15 \mu \mathrm{g} / \mathrm{ml}$, $0.25 \mu \mathrm{g} / \mathrm{g}$ body weight, one shot per day) was injected daily into the peritoneum of mice. Control mice underwent intraperitoneal injection of the identical amounts of saline. The performance of young adult mice on the rotorod test (see below) was significantly impaired when they were tested $24 \mathrm{hr}$ after MK-801 injection, but their performance was as good as that of uninjected control animals when they were tested $36 \mathrm{hr}$ after injection (our unpublished data). We therefore estimate that the effect of a single injection of MK-801 lasts for at least $24 \mathrm{hr}$ but less than $36 \mathrm{hr}$. To apply MK-801 locally to the cerebellum, ethylene-vinyl acetate copolymer (Elvax) containing MK-801 was prepared as described previously (Rabacchi et al., 1992; Jablonska et al., 1995; Schnupp et al., 1995; Smith et al., 1995). In brief, Elvax beads $(100 \mathrm{mg})$ were dissolved into $1 \mathrm{ml}$ of dichloromethane, mixed with $10 \mu \mathrm{l}$ of $2 \%$ Fast green dye in DMSO and $10 \mu \mathrm{l}$ of MK-801 (1000 mM) solution, and stirred until homogenous. The final molarity of MK-801 in the Elvax solution was $\sim 10$ mM. The Elvax solution was plated on a glass dish, frozen quickly at $-70^{\circ} \mathrm{C}$ for $1 \mathrm{hr}$, and then placed at $-20^{\circ} \mathrm{C}$ overnight to allow the dichloromethane to evaporate. Mouse pups were anesthetized with pentobarbital $(15 \mu \mathrm{g} / \mathrm{g})$, and the surface of cerebellar lobules 6-8 was exposed. A piece of Elvax was placed on the cerebellar surface, and the skin was then sutured. MK-801 was released from the Elvax until electrophysiological examination was performed at P24-P36. Schnupp et al. (1995) measured the diffusion of MK-801 from the implanted Elvax (400 $\mu$ m thick; MK-801 concentration in the Elvax solution was $10 \mathrm{~mm}$ ) into the ferret superior colliculus. They estimated that the MK-801 concentration was $\sim 1.5 \mu \mathrm{M}$ at $500 \mu \mathrm{m}$, and significant levels were found within $800 \mu \mathrm{m}$ from the Elvax implant. Because we used the same procedure, we assume that MK-801 was effective in cerebellar tissues within $800 \mu \mathrm{m}$ from the Elvax implant.

Electrophysiology. Parasagittal cerebellar slices (200 $\mu \mathrm{m}$ thickness) were prepared from mice at P24-P36 (Edwards et al., 1989; Aiba et al., 1994; Kano et al., 1995, 1997). Whole-cell recordings were made from visually identified Purkinje cells or granule cells using an upright microscope (Zeiss Axioskop-FS) at room temperature $\left(25^{\circ} \mathrm{C}\right)$ (Edwards et al., 1989; Aiba et al., 1994; Kano et al., 1995, 1997). Resistances of patch pipettes were 3-6 $\mathrm{M} \Omega$ for Purkinje cells and 5-8 $\mathrm{M} \Omega$ for granule cells when filled with an intracellular solution composed of (in $\mathrm{mM}$ ): $60 \mathrm{CsCl}$, $30 \mathrm{Cs}$ D-gluconate, 20 TEA-Cl, 20 BAPTA, $4 \mathrm{MgCl} 2,4$ ATP, and 30 HEPES, ( $\mathrm{pH} 7.3$, adjusted with $\mathrm{CsOH}$ ). The composition of the standard bathing solution was (in mM): $125 \mathrm{NaCl}, 2.5 \mathrm{KCl}, 2 \mathrm{CaCl} 2,1 \mathrm{MgSO}_{4}$, $1.25 \mathrm{NaH}_{2} \mathrm{PO}_{4}, 26 \mathrm{NaHCO}_{3}$, and 20 glucose, bubbled with $95 \% \mathrm{O}_{2}$ and $5 \% \mathrm{CO}_{2}$. Bicuculline $(10 \mu \mathrm{M})$ was added to block spontaneous IPSCs. Ionic currents were recorded with an EPC-9 patch-clamp amplifier (HEKA). The signals were filtered at $3 \mathrm{kHz}$ and digitized at $20 \mathrm{kHz}$. On-line data acquisition and off-line analysis of data were performed using PULSE software (HEKA). A stimulation pipette $(5-10 \mu \mathrm{m}$ tip diameter) was filled with the standard saline and used to apply square pulses for focal stimulation (duration, $0.1 \mathrm{msec}$; amplitude, $0-90 \mathrm{~V}$ for climbing fiber stimulation, $0-10 \mathrm{~V}$ for parallel fiber and mossy fiber stimulation). Climbing fibers were stimulated in the granule cell layer $50-100 \mu \mathrm{m}$ away from the Purkinje cell soma under recording. Parallel fibers were stimulated in the molecular layer at the deeper one-third from the pial surface. The membrane potentials were held at -20 to $-10 \mathrm{mV}$ for recording climbing fiber-mediated (CF)-EPSCs in Purkinje cells and at $-70 \mathrm{mV}$ for recording parallel fiber-mediated (PF)-EPSCs in Purkinje cells and mossy fiber-mediated EPSCs in granule cells, after the compensation of the liquid junction potential.

Morphology. Under deep anesthesia with chloral hydrate $(350 \mathrm{mg} / \mathrm{kg}$, i.p.), mice were perfused transcardially with $4 \%$ paraformaldehyde and $0.5 \%$ glutaraldehyde in $0.1 \mathrm{~m}$ sodium cacodylate buffer, $\mathrm{pH}$ 7.2. The brains were removed quickly and immersed overnight in the same fixative. For comparison of cerebellar histology and measurement of granule cell layer area, midsagittal microslicer sections (50 $\mu \mathrm{m}$ thickness) were Nissl-stained with toluidine blue. To prepare semithin $(1 \mu \mathrm{m})$ and ultrathin $(70-80 \mathrm{~nm})$ sections, midsagittal microslicer sections $(300 \mu \mathrm{m})$ were osmificated and embedded in Epon812. Semithin sections were stained with hematoxylin. From each mouse, 20 light micrographs were taken from the granule cell and molecular layers of the lobule $4 / 5$, to compare the number of granule cells and parallel fiber to Purkinje cell synapses, respectively. The mean area of granule cell layer was obtained by counting points falling onto the granule cell layer, using a transparent double-lattice sheet covering the printed light micrographs (Weibel, 1979). The numerical density (Nv) of granule cells in the granule cell layer was measured from each electron micrograph and calculated using the following equation: $N v=1 / \beta \times N A^{1.5} / V v^{0.5}$, where $N A$ is the visible profile count of granule cell nuclei, $V v$ is the volume density of granule cell nuclei, and $\beta$ is a dimensionless shape coefficient defined as 1.38 by assuming that granule cell nuclei are spherical (Weibel, 1979).

Motor coordination. Mice were placed on the stationary rod (diameter $=5 \mathrm{~cm}$ ) of a rotorod device (Muromachi Kikai, Tokyo, Japan) for up to 2 min until they habituated to the experimental environment. The mice were then carefully placed on the rotating rod $(8 \mathrm{rpm})$, and the time they remained on the rod was measured for each trial. The maximum retention time was $120 \mathrm{sec}$. The mice were allowed to undergo seven pretrials to adapt to the instrument, and the average retention time for the three consecutive trials was then registered for each mouse.

\section{RESULTS}

\section{Critical period for climbing fiber synapse elimination}

To determine the NMDA receptor-dependent period of climbing fiber synapse elimination, we first injected the noncompetitive antagonist MK-801 daily starting at different postnatal days. The number of climbing fibers innervating each Purkinje cell was then estimated electrophysiologically during P24-P36. Whole-cell recording was conducted from visually identified Purkinje cells (Edwards et al., 1989), and climbing fibers were stimulated in the granule cell layer (Kano et al., 1995, 1997, 1998; Offermanns et al., 1997; Watase et al., 1998). When a climbing fiber was stimulated, an EPSC was elicited in an all-or-none fashion (Fig. $1 A$ ). In some Purkinje cells, more than one discrete CF-EPSC could be elicited when the stimulus intensity was increased or when the stimulating electrode was moved to a different site (Fig. $1 B$ ). The number of climbing fibers innervating the Purkinje cell was estimated by counting the number of discrete CF-EPSC steps elicited in that cell (Kano et al., 1995, 1997, 1998; Offermanns et al., 1997; Watase et al., 1998).

Mice that received daily injection of MK-801 for $15 \mathrm{~d}$ from $\mathrm{P} 7$ to P21 had a significantly higher percentage of multiplyinnervated Purkinje cells than saline-injected control mice $(p<$ 0.001, $\chi^{2}$ test) (Fig. 1C). Daily injection of MK-801 for $8 \mathrm{~d}$ from $\mathrm{P} 7$ to $\mathrm{P} 14$ caused no increase in this percentage $\left(p>0.05, \chi^{2}\right.$ test) (Fig. 1D), whereas injecting for $7 \mathrm{~d}$ from P15 to P21 caused a significant increase in the percentage of multiple innervation $\left(p<0.001, \chi^{2}\right.$ test) (Fig. 1E). A 4 d injection of MK-801 from P15 to P18 $\left(p<0.001, \chi^{2}\right.$ test) (Fig. $\left.1 F\right)$ had almost the same effect as injecting the drug from P7 to P21 (Fig. $1 C$ ) or from P15 to $\mathrm{P} 21$ (Fig. 1E). In contrast, daily injection during the fourth postnatal week, from P22 to P28, showed no effect when examined at P31 to P43 (data not shown).

We further narrowed down the period sensitive to NMDA receptor blockade by using a $2 \mathrm{~d}$ injection protocol. Injection of MK-801 at P15 and P16 resulted in the retention of multiple climbing fiber innervation ( $p<0.001, \chi^{2}$ test) (Fig. $\left.1 G\right)$ to the same extent as longer injection protocols covering P15 and P16 (Fig. $1 C, E, F)$. However, injecting at P17-P18 ( $p>0.05, \chi^{2}$ test) (Fig. $1 H$ ) or at P19-P20 (data not shown) did not affect the degree of multiple innervation. These results suggest that NMDA receptor activation during $\mathrm{P} 15-\mathrm{P} 16$ is required for completing climbing fiber synapse elimination.

\section{Cerebellar morphology is normal}

Multiple climbing fiber innervation of Purkinje cells has been reported to persist in animal models that have significant defects 
A

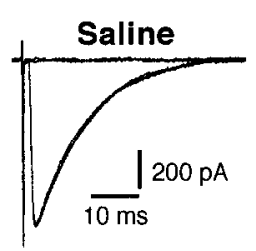

C

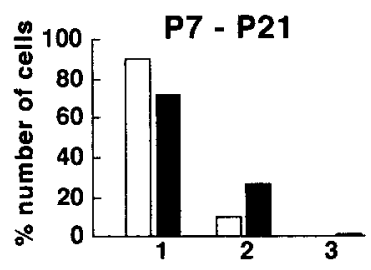

E

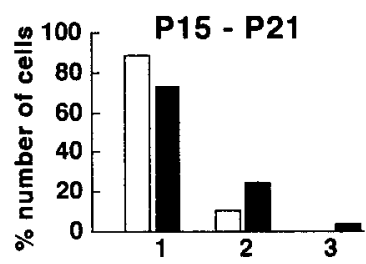

$\mathrm{G}$

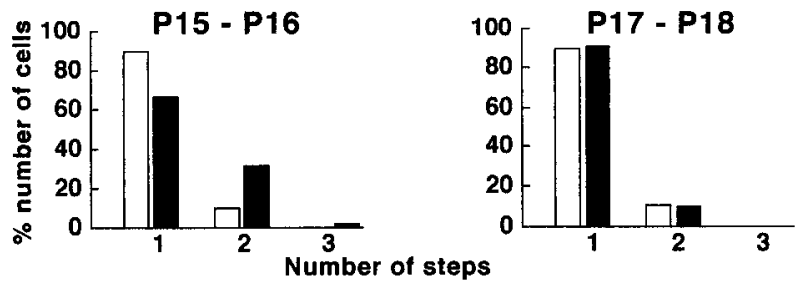

Figure 1. A critical period for climbing fiber synapse elimination. $A, B$, CF-EPSCs recorded from Purkinje cells in saline-injected $(A$, Saline $)$ and MK-801-injected $[B, M K-801$ (P15-P16)] mice. Two to three traces are superimposed at each threshold stimulus intensity. $C-H$, Frequency distributions of Purkinje cells in terms of the number of discrete CF-EPSC steps. The closed bars represent data obtained from mice that underwent daily intraperitoneal injection of MK-801 during P7-P21 (C, from 13 mice, 93 cells), P7-P14 ( $D$, from 7 mice, 102 cells), P15-P21 ( $E$, from 7 mice, 69 cells), P15-P18 ( $F$, from 4 mice, 38 cells), P15-P16 ( $G$, from 6 mice, 48 cells), or P17-P18 ( $H$, from 7 mice, 72 cells). The open bars represent the same set of control data obtained from mice that underwent daily intraperitoneal injection during the period during P7-P21 (from 11 mice, 89 cells). The difference between the frequency distribution from MK-801treated mice and that from control mice was highly significant in $C, E, F$, and $G\left(p<0.001, \chi^{2}\right.$ test $)$, whereas the difference is not significant in $D$ and $H\left(p>0.05, \chi^{2}\right.$ test $)$. All Purkinje cells for this Figure and for Figure 3 were studied under blind conditions; the experimenters did not know whether the mice had been injected with MK-801 or saline.

in granule cell survival or in parallel fiber-Purkinje cell synaptogenesis. These include x-irradiated rats (Woodward et al., 1974; Crépel and Delhaye-Bouchaud, 1979), weaver mice (Crépel and Mariani, 1976), reeler mice (Mariani et al., 1977), staggerer mice (Crépel et al., 1980; Mariani and Changeux, 1980), and mice in which the glutamate receptor (GluR) $\delta 2$ subunit has been knocked out genetically (Kashiwabuchi et al., 1995). It is important, therefore, to examine whether the blockade of NMDA receptors by MK-801 had any effects on granule cell survival or parallel fiber-Purkinje cell synapse formation.

We examined cerebellar morphology by using midsagittal cerebellar sections from P28 mice (Fig. 2). Characteristics that were examined included cerebellar size and shape, foliation, and trilaminar cortical organization (i.e., molecular layer, Purkinje cell layer, and granule cell layer) (Fig. 2A,B). No appreciable differences were found in any of these anatomical characteristics be-
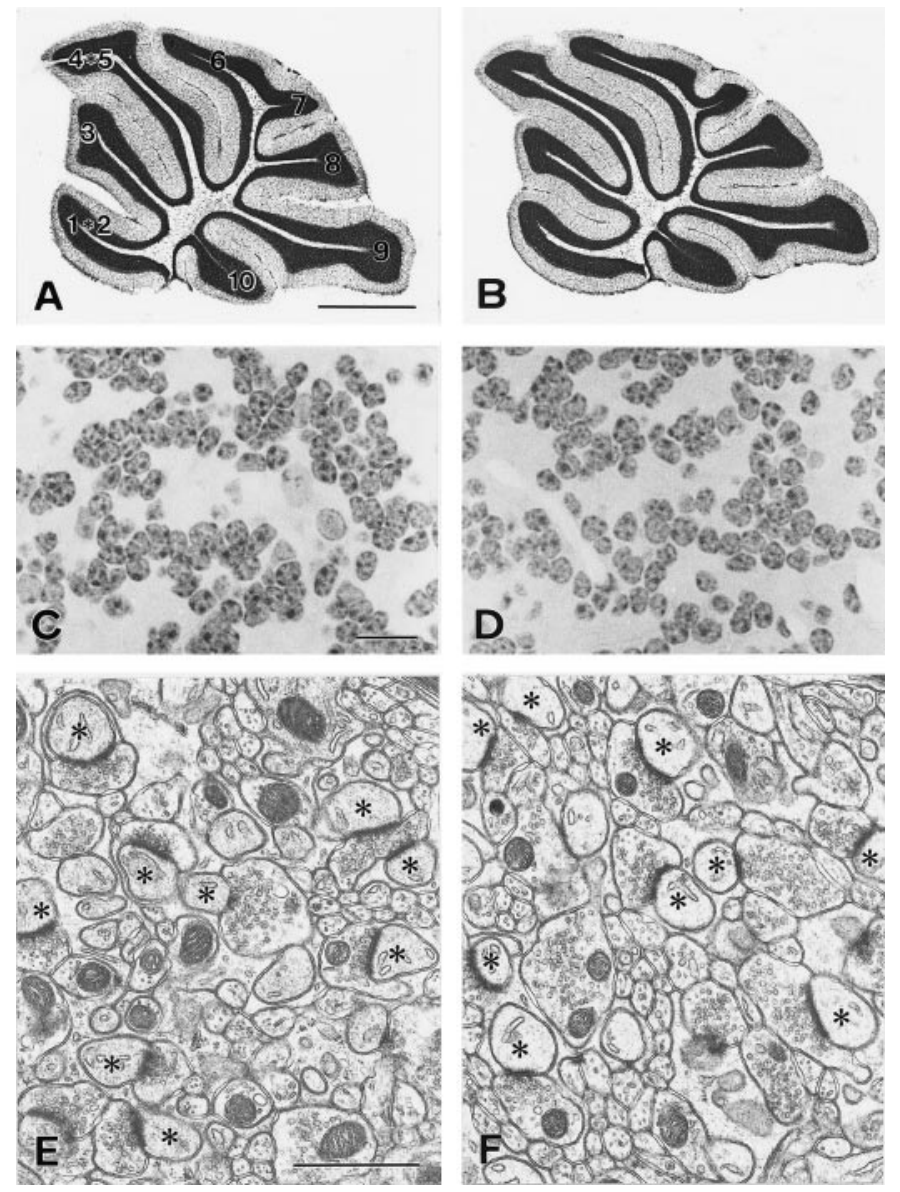

Figure 2. Cerebellar histology and ultrastructure in the control $(A, C, E)$ and MK-801-treated $(B, D, F)$ mice. $A, B$, Light micrographs of Nisslstained midsagittal sections. $C, D$, Light micrographs of hematoxylinstained granule cell layer. $E, F$, Electron micrographs of the molecular layer. Micrographs were obtained from mice that underwent daily intraperitoneal injection of saline $(A, C, E)$ or MK-801 $(B, D, F)$. Asterisks indicate Purkinje cell dendritic spines in contact with parallel fiber terminals. Scale bar: $A, B, 1 \mathrm{~mm} ; C, D, 10 \mu \mathrm{m} ; E, F, 1 \mu \mathrm{m}$.

tween mice injected with MK-801 during P15-P18 and control mice injected with saline. Microslicer sections were used to measure the mean area of the granule cell layer by the point-counting method of Weibel (1979). The mean area of granule cells was $2.49 \pm 0.08 \mathrm{~mm}^{2}$ for MK-801-treated mice and $2.72 \pm 0.21 \mathrm{~mm}^{2}$ for saline-treated mice, showing no significant difference $(p>$ $0.05, n=3, t$ test). With $1-\mu \mathrm{m}$-thick plastic sections, the numerical density of granule cells was evaluated morphometrically and also showed no significant difference ( $p>0.05, n=3, t$ test), being $3.91 \pm 0.87\left(\times 10^{6} / \mathrm{mm}^{3}\right.$ of granule cell layer $)$ in MK801-treated mice and $3.68 \pm 0.32$ in control mice. From the mean area of the granule cell layer and the numerical density of granule cells, the number of granule cells contained in a 1-mm-thick cerebellar slice was estimated to be $10.63 \pm 0.84 \times 10^{6}$ in MK-801-treated mice and $9.20 \pm 0.97 \times 10^{6}$ in saline-treated mice, again showing no significant difference ( $p>0.05, n=3, t$ test).

Because blockade of NMDA receptors is reported to affect granule cell migration in cerebellar slices at P10 (Komuro and Rakic, 1993), we analyzed the cerebellar morphology of the mice injected with MK-801 during P7-P14. We did not find any significant difference in either the mean area of the granule cell layer (2.68 \pm 0.29 and $2.62 \pm 0.37 \mathrm{~mm}^{2}$ for the MK-801-treated and the 


\begin{tabular}{|c|c|c|c|c|c|}
\hline EPSC & Group & $10-90 \%$ Rise time (msec) & Decay time constant (msec) & Amplitude $(\mathrm{pA})^{a}$ & Paired-pulse ratio $(\%)^{b}$ \\
\hline \multirow[t]{4}{*}{ CF-EPSC } & Control (sg) & $0.6 \pm 0.1(n=50)$ & $9.3 \pm 2.1(n=50)$ & $653 \pm 211(n=29)$ & $81.0 \pm 5.2(n=58)$ \\
\hline & MK-801 (sg) & $0.6 \pm 0.1(n=53)$ & $9.4 \pm 2.7(n=53)$ & $736 \pm 209(n=43)$ & $81.8 \pm 6.6(n=65)$ \\
\hline & MK-801 (mlt-L) & $0.5 \pm 0.1(n=17)$ & $8.9 \pm 2.4(n=17)$ & $677 \pm 238(n=14)$ & $81.2 \pm 6.7(n=20)$ \\
\hline & MK-801 (mlt-S) & $0.9 \pm 0.6(n=15)$ & $10.4 \pm 3.9(n=15)$ & $267 \pm 134(n=13)^{*}$ & $73.6 \pm 11.3(n=17)^{* *}$ \\
\hline \multirow[t]{3}{*}{ PF-EPSC } & Control (sg) & $1.6 \pm 0.4(n=20)$ & $16.0 \pm 4.0(n=20)$ & & $175 \pm 26(n=10)$ \\
\hline & MK-801 (sg) & $1.5 \pm 0.5(n=19)$ & $14.5 \pm 4.5(n=19)$ & & $177 \pm 31(n=10)$ \\
\hline & MK-801 (mlt) & $1.5 \pm 0.4(n=9)$ & $14.1 \pm 3.7(n=9)$ & & $183 \pm 25(n=6)$ \\
\hline
\end{tabular}

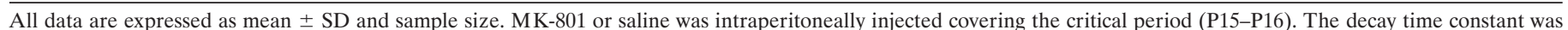
obtained by fitting the EPSC decay with a single exponential.

${ }^{*} p<0.01,{ }^{* *} p<0.001$, compared with Control (sg) $(t$ test).

${ }^{a}$ Amplitude of CF-EPSCs was measured at the holding potential (Vh) of $-20 \mathrm{mV}$.

${ }^{b}$ Second EPSC/first EPSC: interpulse intervals were $100 \mathrm{msec}$ for CF-EPSC and $50 \mathrm{msec}$ for PF-EPSC.

saline-treated mice, respectively; $p>0.05, n=3, t$ test) or the numerical density of granule cells [3.49 \pm 0.90 and $3.72 \pm 1.40$ $\left(\times 10^{6} / \mathrm{mm}^{3}\right.$ of granule cell layer) for the MK-801-treated and the control mice, respectively; $p>0.05, n=3, t$ test]. Therefore, the granule cell migration was completed normally in the mature mice injected with MK-801 during P7-P14.

The formation of parallel fiber-Purkinje cell synapses was analyzed by electron microscopy in mice treated with MK-801 during P15-P18 (Kano et al., 1995, 1997, 1998; Kurihara et al., 1997; Offermanns et al., 1997; Watase et al., 1998). In both mice, the molecular layer contained numerous profiles of parallel fiberPurkinje cell synapses (Fig. 2E,F). These synapses were observed as asymmetrical contacts between parallel fiber terminals that contained clear, round synaptic vesicles and Purkinje cell spines having smooth endoplasmic reticulum and well developed postsynaptic densities ranging from 0.3 to $1.0 \mu \mathrm{m}$ in size. The number of parallel fiber synapse profiles per $100 \mu \mathrm{m}^{2}$ was $23.6 \pm$ 1.0 in the MK-801-treated mice and $21.5 \pm 0.5$ in the control mice, showing no significant difference ( $p>0.05, n=3, t$ test). Therefore, cerebella treated with MK-801 are normal in their histoarchitecture, granule cell number, and number of parallel fiber-Purkinje cell synapses.

\section{Basic synaptic properties}

The basic electrophysiological properties of CF-EPSCs and PFEPSCs were compared in mice injected with MK-801 or saline at P15 and P16 (Table 1). There was no significant difference in the $10-90 \%$ rise time, the decay time constant, or the extent of paired-pulse depression (Konnerth et al., 1990; Hashimoto and Kano, 1998) of EPSCs recorded from singly innervated Purkinje cells in the two groups of mice (Table 1). The kinetics and paired-pulse depression of the largest CF-EPSCs recorded from multiply innervated Purkinje cells in MK-801-treated mice [MK801 (mlt-L)] were similar to those of CF-EPSCs of singly innervated Purkinje cells in the two groups of mice [Control (sg) and MK-801 (sg)] (Table 1). On the other hand, the smaller CFEPSCs of the multiply innervated Purkinje cells in the MK-801treated mice [MK-801 (mlt-S)] had slower rise time and stronger paired-pulse depression than MK-801 (mlt-L), Control (sg), or MK-801 (sg) (Table 1). This suggests that the transmitter release may be less synchronized and it may take longer time to replenish the readily releasable pool at climbing fiber terminals that generate smaller CF-EPSCs than those that generate the largest EPSCs in MK-801-injected mice. The current-voltage relations of CF-EPSCs were linear in both monoinnervated and multiply innervated Purkinje cells derived from the two groups of mice (data not shown). PF-EPSCs also were similar between MK-801treated and control mice. There was no significant difference in the kinetics of PF-EPSCs or in the extent of paired-pulse facilitation (Konnerth et al., 1990; Hashimoto and Kano, 1998) among monoinnervated Purkinje cells from control or MK-801-treated mice, or in multiply innervated Purkinje cells from MK-801treated mice (Table 1).

\section{Location of NMDA receptors responsible for climbing fiber synapse elimination}

Intraperitoneal injection of MK-801 may also affect NMDA receptors in other brain regions. To examine whether NMDA receptors within the cerebellum are responsible for climbing fiber synapse elimination, we locally applied MK-801 to the cerebellum by continuous inf usion from Elvax implants (Rabacchi et al., 1992; Jablonska et al., 1995; Schnupp et al., 1995; Smith et al., 1995). A small piece of Elvax containing MK-801 or vehicle was placed on the surface of the cerebellar vermis (lobules 6-8) at either P14 or P17, and the effects on climbing fiber synapse elimination were then examined at P24-P36 (Fig. 3A). We first analyzed the morphology of the cerebellar lobule 8 in mice that underwent implantation of MK-801- or vehicle-containing Elvax at P14. No significant difference was found in either the mean area of the granule cell layer $\left(2.67 \pm 0.32\right.$ and $2.71 \pm 0.13 \mathrm{~mm}^{2}$ for the MK-801-treated and the vehicle-treated mice, respectively; $p>0.05, n=3, t$ test) or the numerical density of granule cells $\left[3.74 \pm 0.76\right.$ and $3.47 \pm 1.20\left(\times 10^{6} / \mathrm{mm}^{3}\right.$ of granule cell layer) for the MK-801- and vehicle-treated mice, respectively; $p>$ $0.05, n=3, t$ test]. These values were similar to those of the control mice injected with intraperitoneal saline. Thus, the Elvax implantation in itself caused no significant morphological changes of the cerebellum. In electrophysiological examination of climbing fiber innervation, results from MK-801-treated and vehicletreated mice were compared to exclude possible nonspecific effects attributable to the surgical procedure or vehicle application. In addition, to estimate the extent of MK-801 diff usion in vivo, we compared results from cerebellar lobules 6-8 (those closest to the Elvax implant) with those from lobules $1 / 2$ and 10 (farthest from the implant).

CF-EPSCs were readily elicited in response to granule cell layer stimulation in both vehicle-treated (Fig. 3B) and MK-801treated mice (Fig. 3C,D). Lobules $6-8$ of mice implanted with MK-801-containing Elvax at P14 had a significantly higher percentage of Purkinje cells with multiple CF-EPSC steps than vehicle-treated control mice $\left(p<0.001, \chi^{2}\right.$ test) (Fig. $\left.3 E\right)$. However, lobules $1 / 2$ and 10 showed no significant difference between 
A

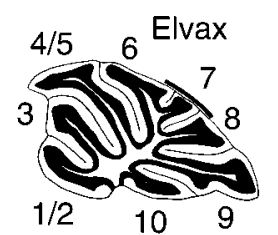

C

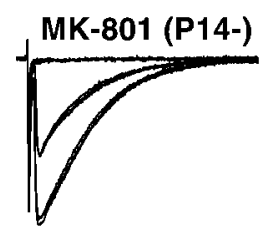

$\mathbf{E}$

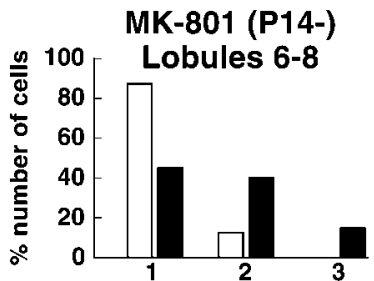

G

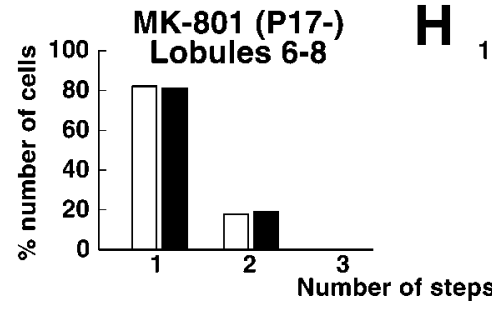

Figure 3. NMDA receptors within the cerebellum are responsible for climbing fiber synapse elimination. $A$, Experimental procedure for chronic and local application of MK-801 by means of Elvax. $B-D$, Climbing fiber EPSCs recorded from Purkinje cells in cerebellar lobules 6-8 from mice treated with vehicle beginning at P14 [B, Vehicle (P14-)], with MK-801 beginning at P14 [C, MK-801 (P14-)]), and with MK-801 beginning at P17 [D, MK-801 (P17-)]). Two to three traces are superimposed at each threshold stimulus intensity. $E-H$, Frequency distributions of the number of Purkinje cells exhibiting the indicated number of CF-EPSCs in lobules 6-8 $(E, G)$ and lobules $1 / 2$ and $10(F, H)$ from mice treated with MK-801 beginning at P14 (E, F, closed bars) or P17 (G, H, closed bars $)$ and of vehicle-treated mice $(E-H$, open bars $)$. Data were obtained from 7 mice treated with MK-801 beginning at P14 (40 cells in lobules 6-8, 48 cells in lobules $1 / 2$ and 10), 5 mice treated with MK-801 beginning at P17 (42 cells in lobules $6-8,32$ cells in lobules $1 / 2$ and 10), 7 mice treated with vehicle beginning at P14 (63 cells in lobules $6-8,49$ cells in lobules $1 / 2$ and 10), and 14 mice treated with vehicle beginning at P17 (134 cells in lobules $6-8,76$ cells in lobules $1 / 2$ and 10 ). The difference between the frequency distributions from MK-801-treated mice and saline-injected control mice was highly significant in $E$ ( $p<0.001, \chi^{2}$ test), whereas the difference was not significant in $F-H$ ( $p>0.05, \chi^{2}$ test).

the two ( $p>0.05, \chi^{2}$ test) (Fig. $\left.3 F\right)$. These results suggest that the effect of locally applied MK-801 is confined to the cerebellar lobules near the implants and that this local action of MK-801 is sufficient to impair climbing fiber synapse elimination. In contrast, MK-801 treatment starting at P17 yielded no significant increase in the percentage of multiply innervated Purkinje cells in lobules $6-8$ (Fig. $3 G$ ) or in lobules $1 / 2$ and 10 (Fig. $3 H$ ). The data suggest that the blockade of NMDA receptors in the cerebellum starting at P14, but not at P17, is effective to prevent climbing fiber synapse elimination. Thus, the intraperitoneal injections of MK-801 probably were affecting elimination of climbing fiber synapses (Fig. 1) by affecting NMDA receptors in the cerebellum.

Excitatory synaptic transmission onto Purkinje cells in young
A

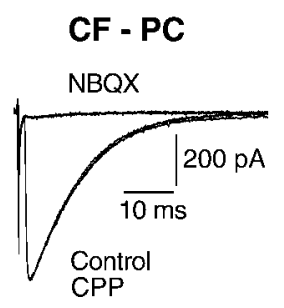

B

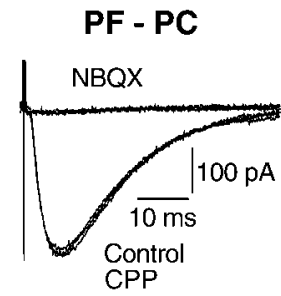

C

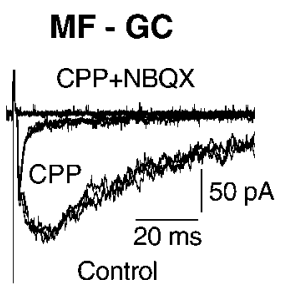

Figure 4. NMDA receptors are localized to mossy fiber-granule cell synapses during the critical period. EPSCs recorded during P15-P16 from Purkinje cells $(A, B)$ or granule cells $(C)$ in response to stimulation of climbing fibers $(A, C F-P C)$, parallel fibers $(B, P F-P C)$, or mossy fibers $(C, M F-G C)$. Slices were perfused with $\mathrm{Mg}^{2+}$-free control saline containing bicuculline $(10 \mu \mathrm{M})$, glycine $(10 \mu \mathrm{M})$, and strychnine $(10 \mu \mathrm{M})$. Superimposed are two to three traces recorded in the control bath solution, in the presence of R-CPP $(5$ or $10 \mu \mathrm{M})$, and after blockade of EPSCs by NBQX $(A, B, 1.25$ or $2.5 \mu \mathrm{M})$ or by CPP plus NBQX $(C)$.

mice is mediated by non-NMDA receptors (Aiba et al., 1994; Kano et al., 1995), whereas mossy fiber to granule cell transmission involves both NMDA and non-NMDA receptors (Ebradlidze et al., 1996; Kadotani et al., 1996; Takahashi et al., 1996). We next examined whether this is also the case for the mouse cerebellum during the critical period for elimination of the climbing fiber synapse (P15-P16). Recordings were made under conditions that should maximize NMDA receptor-mediated currents: namely, using $\mathrm{Mg}^{2+}$-free external Ringer's solution containing glycine $(10 \mu \mathrm{M})$. Neither CF-EPSCs $(n=5)$ nor PF-EPSCs $(n=5)$ were affected by the selective NMDA receptor antagonist 3-(R-2-carboxypiperazin-4-yl)-propyl-1-phosphonic acid (R-CPP, $10 \mu \mathrm{M}$ ) or by D-2-amino-5-phosphonopentanoic acid (D-AP5, $100 \mu \mathrm{M}$ ). Both PF-EPSCs and CF-EPSCs were completely blocked by non-NMDA receptor antagonists 6-nitro-7sulfamoylbenzo[f]quinoxaline-2,3-dione (NBQX, $2.5 \mu \mathrm{M}$ ) and 6-cyano-7-nitroquinoxaline-2,3-dione (CNQX, $15 \mu \mathrm{M})$ (Figs. $4 A, B)$. In contrast, mossy fiber-mediated EPSCs recorded from granule cells $(n=6)$ had a clear NMDA receptor-mediated component that was completely blocked by application of R-CPP (or AP5) (Fig. 4C). Therefore, synaptic transmission at neither the climbing fiber to Purkinje cell nor the parallel fiber to Purkinje cell synapse is mediated by NMDA receptors at P15-P16.

\section{Mild motor discoordination in mice with persistent multiple climbing fiber innervation}

Ataxia and loss of motor coordination occur in several strains of mutant mice with persistent multiple climbing fiber innervation (Aiba et al., 1994; Chen et al., 1995; Conquet et al., 1994; Kano et al., 1995, 1997, 1998; Kashiwabuchi et al., 1995; Levenes et al., 1997; Offermanns et al., 1997; Watase et al., 1998). Mice injected with intraperitoneal MK-801 during the critical period (P15-P16) retained persistent multiple climbing fiber innervation but displayed no obvious signs of cerebellar symptoms, such as ataxic gait or intention tremor. However, these mice displayed a clear impairment in their motor coordination when tested on a rotorod ( $8 \mathrm{rpm}$ speed). The time that they remained on the rotorod (retention time) was significantly shorter than that of salineinjected control mice ( $p<0.001, t$ test) (Fig. 5). On the other hand, mice injected with MK-801 before P14 or after P17 had normal climbing fiber innervation (Fig. 5, bottom) and showed no significant differences in retention time from the control mice (Fig. 5, top). Therefore, NMDA receptor blockade during P15- 


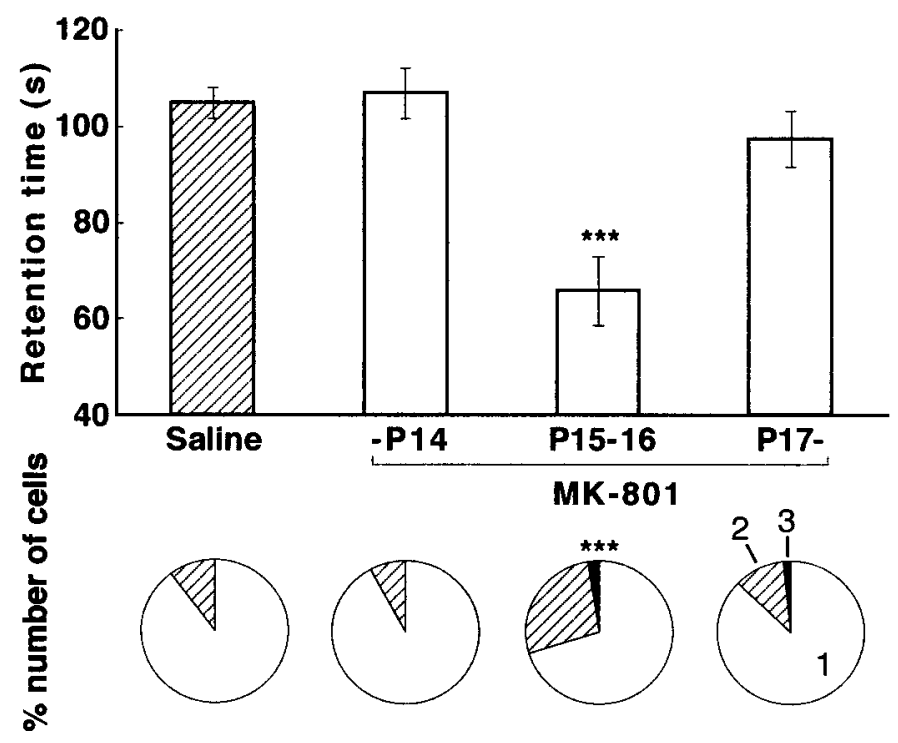

Figure 5. Mild motor discoordination in the mice with persistent multiple climbing fiber innervation caused by MK- 801 treatment. Bar graph displays the retention time (mean \pm SEM) on the rotating rod $(8 \mathrm{rpm})$ of the mice with daily intraperitoneal injection of saline (Saline, $n=20)$, that of MK-801 for at least $2 \mathrm{~d}$ until P14 (-P14, $n=19)$, that of MK-801 including P15 and P16 $(P 15-P 16, n=27)$, and that of MK-801 for at least $2 \mathrm{~d}$ later than P17 (P17-, $n=15)$. After performance on the rotating rod was evaluated, each mouse was killed, and the climbing fiber innervation pattern was examined in cerebellar slices from these mice. The bottom panel indicates the proportion of Purkinje cells in terms of the number of CF-EPSC steps for the mice whose retention times are indicated in the bar graph. The mice were part of the experimental groups described in Figure 1 . ${ }^{* *} p<0.001$, compared with the value of saline-injected mice ( $t$ test for the rotorod test and $\chi^{2}$ test for climbing fiber innervation).

P16 specifically impairs both motor coordination and regression of multiple climbing fiber innervation. These results support the notion that the normal regression of multiple climbing fiber innervation is essential for motor coordination.

\section{DISCUSSION}

\section{Critical period for NMDA receptor-dependent climbing fiber synapse elimination}

Activity-dependent synaptic refinement has been well investigated in developing sensory systems, including the visual cortex (Chapman et al., 1986) and the somatosensory system (O'Leary et al., 1994; Kutsuwada et al., 1996; Iwasato et al., 1997). In these systems, disrupting neural activity at a certain period of development causes immature types of synaptic connections to persist throughout life, whereas the same disruptions have little effect if applied after the critical period. In mice, the duration of the critical period for organization of ocular dominance columns is $\sim 2$ weeks (P19-P32) (Gordon and Stryker, 1996), and the critical period for formation of whisker barrels is $\sim 7 \mathrm{~d}$ (P0-P7) (Vitalis et al., 1998; Toki et al., 1999). In the present study, we found that blockade of NMDA receptors for as short as $2 \mathrm{~d}$ (P15 and P16) prevented elimination of climbing fiber synapses and caused mild but persistent impairment of motor coordination. However, NMDA receptor blockade before or after this critical period was ineffective. Our findings that MK-801 application from P7 to P14 or beginning at $\mathrm{P} 17$ had no effect indicate that the critical period lies within P15 and P16. Behavioral criteria suggested that the effect of a single intraperitoneal injection of MK-801 lasted >24 hr but $<36 \mathrm{hr}$, so it is difficult to determine whether the critical period is even shorter than these $2 \mathrm{~d}$. We thus conclude that there is a sharply defined critical period for NMDA receptordependent climbing fiber synapse elimination. When NMDA receptors are activated during this critical period, the pattern of climbing fiber innervation is refined, and motor coordination is preserved throughout life.

\section{Multiple phases of climbing fiber synapse elimination}

When MK-801 was applied from P7 to P14, there was no effect on regression of multiple climbing fiber innervation. Therefore, elimination of climbing fiber synapses during the second postnatal week appears to be mediated by mechanisms that do not rely on NMDA receptors. Mariani et al. (1990) reported that the "critical period" for x-irradiation to cause persistent multiple climbing fiber innervation in the rat is from P4 to P7. This suggests that climbing fiber synapse elimination is most sensitive to granule cell generation from P4 to P7 in the rat. This phase, however, does not seem to depend on NMDA receptors, because mossy fiber-granule cell synapses are immature, and Purkinje cells have no functional NMDA receptors during this period. Taken together, these results suggest that elimination of climbing fiber synapses occurs in at least three distinct phases: (1) an early phase during the first postnatal week (P4-P7 in the rat) that depends on granule cell genesis; (2) a second phase during the second postnatal week that is independent of NMDA receptormediated neural activity; and (3) a third phase during P15-P16 that depends on NMDA receptor-mediated neural activity.

\section{Involvement of mGluR subtype 1-mediated signal transduction}

During the critical period, large NMDA receptor-mediated EPSCs were detected at the mossy fiber-granule cell synapse but not at the parallel fiber-Purkinje cell synapse or the climbing fiber-Purkinje cell synapse. It is most likely that the NMDA receptors located at the mossy fiber-granule cell synapse mediate signals leading to the elimination of surplus climbing fibers. A number of knockout mice with defects in the mGluR subtype 1 (mGluR1) or its downstream signal transduction pathway also exhibit defects in elimination of climbing fiber synapses. mGluR1 is the major subtype of the metabotropic glutamate receptor expressed in Purkinje cells (Masu et al., 1991; Nakanishi, 1994) and is activated at parallel fiber-Purkinje cell synapses (Finch and Augustine, 1998; Takechi et al., 1998). The signaling pathway downstream of mGluR1 in Purkinje cells is thought to include the $\alpha$ subunit of the $\mathrm{Gq}$ subtype of GTP-binding protein $(\mathrm{G} \alpha \mathrm{q})$ (Offermanns et al., 1997), phospholipase C $\beta 4$ (PLC $\beta 4$ ) (Kano et al., 1998), and protein kinase $\mathrm{C} \gamma(\mathrm{PKC} \gamma)$ (Kano et al., 1995). Similar to mice treated with MK-801, adult mice defective in mGluR1 (Kano et al., 1997; Levenes et al., 1997), G $\alpha$ q (Offermanns et al., 1997), PLC $\beta 4$ (Kano et al., 1998), or PKC $\gamma$ (Kano et al., 1995) all exhibit persistent multiple climbing fiber innervation despite the normal formation and function of the parallel fiber-Purkinje cell synapse. Impairment of climbing fiber synapse elimination in these knockout mice is not manifest during the first and second postnatal weeks but instead becomes obvious during the third postnatal week (Kano et al., 1995, 1997, 1998; Offermanns et al., 1997), the time that our work reveals to be the critical period for NMDA receptor-dependent elimination of climbing fiber synapses. It is thus conceivable that neural activity mediated by NMDA receptors at the mossy fiber-granule cell synapse and by mGluR1 at the parallel fiber-Purkinje cell synapse is important for the elimination of surplus climbing fibers. 
This notion is consistent with previous reports that related climbing fiber synapse elimination to the presence of granule cells (Woodward et al., 1974; Crépel and Mariani, 1976; Crépel and Delhaye-Bouchaud, 1979) or the formation of parallel fiberPurkinje cell synapses (Crépel et al., 1980; Mariani and Changeux, 1980; Kashiwabuchi et al., 1995). Taken altogether, these results indicate that establishment of functional pathways at the mossy fiber-granule cell synapse and the parallel fiber-Purkinje cell synapse is essential for the refinement of climbing fiberPurkinje cell synapses.

In the second postnatal week, Purkinje cell extend well arborized dendritic trees, innumerable granule cells migrate into the internal granular layer (Ito, 1984; Altman and Bayer, 1997), and parallel fiber synapses with mature structure and function emerge on distal Purkinje cell dendrites (Kurihara et al., 1997). During this week, expression of the NMDA receptor GluR $\epsilon 3$ (NR2C) subunit dramatically increases in granule cells (Watanabe et al., 1992, 1994; Didier et al., 1995). NMDA receptormediated EPSCs at mossy fiber-granule cell synapses become less sensitive to voltage-dependent $\mathrm{Mg}^{2+}$ block as GluR $\epsilon 3$ expression increases (Takahashi et al., 1996). Accordingly, the critical period for NMDA receptor-dependent climbing fiber elimination corresponds to the stage when synaptic wiring in the cerebellar ascending pathway has almost reached a mature state of both structure and function. NMDA receptors are present persistently at mossy fiber-granule cell synapses after the critical period (Takahashi et al., 1996; Watanabe et al., 1998). However, climbing fiber synapse elimination appears to complete during P15 and P16, because the degree of multiple climbing fiber innervation in mice at P18-P19 is similar to that in adult mice (K. Hashimoto, S. Kakisawa, and M. Kano, unpublished observation). Thus, neural activity during the short critical period eventually may produce NMDA receptor-mediated signals sufficient to trigger and accomplish the final phase of climbing fiber synapse refinement. This also coincides well with the period in which PKC $\gamma$ expression in Purkinje cells increases (Huang et al., 1990). It is not known, however, how signaling involving PKC $\gamma$ eventually causes elimination of surplus climbing fibers. Future studies should elucidate molecules downstream from PKC $\gamma$ or other signaling pathways that may function in parallel to the mGluR1 cascade during the critical period.

\section{REFERENCES}

Aiba A, Kano M, Chen C, Stanton ME, Fox GD, Herrup K, Zwingman TA, Tonegawa S (1994) Deficient cerebellar long-term depression and impaired motor learning in mGluR1 mutant mice. Cell 79:377-388.

Altman J, Bayer SA (1997) Development of the cerebellar system. Boca Raton, FL: CRC.

Changeux JP, Courrege P, Danchin A (1973) A theory of epigenesis of neuronal networks by selective stabilization of synapses. Proc Natl Acad Sci USA 70:2974-2978.

Chapman B, Jacobson MD, Reiter HO, Stryker MP (1986) Ocular dominance shift in kitten visual cortex caused by imbalance in retinal electrical activity. Nature 324:154-156.

Chen C, Kano M, Abeliovich A, Chen L, Bao S, Kim JJ, Hashimoto K, Thompson RF, Tonegawa S (1995) Impaired motor coordination correlates with persistent multiple climbing fiber innervation in PKC $\gamma$ mutant mice. Cell 83:1233-1242.

Conquet F, Bashir ZI, Davies CH, Daniel H, Ferraguti F, Bordi F, Franz-Bacon K, Reggiani A, Matarese V, Conde F, Collingridge GL, Crépel F (1994) Motor deficit and impairment of synaptic plasticity in mice lacking mGluR1. Nature 372:237-243.

Crépel F (1982) Regression of functional synapses in the immature mammalian cerebellum. Trends Neurosci 5:266-269.

Crépel F, Mariani J (1976) Multiple innervation of Purkinje cells by climbing fibers in the cerebellum of the weaver mutant mouse. J Neurobiol 7:579-582.

Crépel F, Delhaye-Bouchaud N (1979) Distribution of climbing fibers on cerebellar Purkinje cells in X-irradiated rats. An electrophysiological study. J Physiol (Lond) 290:97-112.

Crépel F, Delhaye-Bouchaud N, Gustavino JM, Sampaio I (1980) Multiple innervation of cerebellar Purkinje cells by climbing fibres in staggerer mutant mouse. Nature 283:483-484.

Didier M, Xu M, Berman SA, Bursztajn S (1995) Differential expression and co-assembly of NMDA zeta 1 and epsilon subunits in the mouse cerebellum during postnatal development. NeuroReport 6:2255-2259.

Ebradlidze AK, Rossi DJ, Tonegawa S, Slater NT (1996) Modification of NMDA receptor channels and synaptic transmission by targeted disruption of the NR2C gene. J Neurosci 16:5014-5025.

Edwards FA, Konnerth A, Sakmann B, Takahashi T (1989) A thin slice preparation for patch-clamp recordings from neurons of the mammalian central nervous system. Pflügers Arch 414:600-612.

Finch EA, Augustine GJ (1998) Local calcium signalling by inositol1,4,5-trisphosphate in Purkinje cell dendrites. Nature 396:753-756.

Gordon J, Stryker MP (1996) Experience-dependent plasticity of binocular responses in the primary visual cortex of the mouse. J Neurosci 16:3274-3286.

Hashimoto K, Kano M (1998) Presynaptic origin of paired-pulse depression at climbing fibre to Purkinje cell synapses in the rat cerebellum. J Physiol (Lond) 506:391-405.

Huang FL, Yaung WS, Yoshida Y, Huang K-P (1990) Developmental expression of protein kinase $\mathrm{C}$ isozymes in rat cerebellum. Dev Brain Res 52:121-130.

Ito M (1984) The cerebellum and neural control. New York: Raven.

Iwasato T, Erzurumlu RS, Huerta PT, Chen DF, Sasaoka T, Ulupinar E, Tonegawa S (1997) NMDA receptor-dependent refinement of somatotopic maps. Neuron 19:1201-1210.

Jablonska B, Gierdalski M, Siucinska E, Skangie-Kramska J, Kossut M (1995) Partial blocking of NMDA receptors restricts plastic changes in adult mouse barrel cortex. Behav Brain Res 66:207-216.

Kadotani H, Hirano T, Masugi M, Nakamura K, Nakao K, Katsuki M, Nakanishi S (1996) Motor discoordination results from combined gene disruption of the NMDA receptor NR2A and NR2C subunits, but not from single disruption of the NR2A or NR2C subunit. J Neurosci 16:7859-7867.

Kano M, Hashimoto K, Chen C, Abeliovich A, Aiba A, Kurihara H, Watanabe M, Inoue Y, Tonegawa S (1995) Impaired synapse elimination during cerebellar development in $\mathrm{PKC} \gamma$ mutant mice. Cell 83:1223-1231.

Kano M, Hashimoto K, Kurihara H, Watanabe M, Inoue Y, Aiba A, Tonegawa S (1997) Persistent multiple climbing fiber innervation of cerebellar Purkinje cells in mice lacking mGluR1. Neuron 18:71-79.

Kano M, Hashimoto K, Watanabe M, Kurihara H, Inoue Y, Offermanns S, Jiangs H, Wu Y, Jun K, Shin H-S, Simon M I, Wu D (1998) PLC $\beta 4$ is specifically involved in climbing fiber synapse elimination in the developing cerebellum. Proc Natl Acad Sci USA 95:15724-15729.

Kashiwabuchi N, Ikeda K, Araki K, Hirano T, Shibuki K, Takayama C, Inoue Y, Kutsuwada T, Yagi T, Kang Y, Aizawa S, Mishina M (1995) Impairment of motor coordination, Purkinje cell synapse formation, and cerebellar long-term depression in GluR $\delta 2$ mutant mice. Cell 81:245-252.

Katz LC, Shatz CJ (1996) Synaptic activity and the construction of cortical circuits. Science 274:1133-1138.

Komuro H, Rakic P (1993) Modulation of neuronal migration by NMDA receptors. Science 260:95-97.

Konnerth A, Llano I, Armstrong CM (1990) Synaptic currents in cerebellar Purkinje cells. Proc Natl Acad Sci USA 87:2662-2665.

Kurihara H, Hashimoto K, Kano M, Takayama C, Sakimura K, Mishina M, Inoue Y, Watanabe M (1997) Impaired parallel fiber-Purkinje cell synapse stabilization during cerebellar development of mutant mice lacking the glutamate receptor $\delta 2$ subunit. J Neurosci 17:9613-9623.

Kutsuwada T, Sakimura K, Manabe T, Takayama C, Katakura N, Kushiya E, Natsume R, Watanabe M, Inoue Y, Yagi T, Aizawa S, Arakawa M, Takahashi T, Nakamura Y, Mori H, Mishina M (1996) Impairment of suckling response, trigeminal neuronal pattern formation, and hippocampal LTD in NMDA receptor $\epsilon 2$ subunit mutant mice. Neuron 16:333-344.

Levenes C, Daniel H, Jaillard D, Conquet F, Crépel F (1997) Incomplete regression of multiple climbing fibre innervation of cerebellar Purkinje cells in mGluR1 mutant mice. NeuroReport 20:571-574. 
Li Y, Erzurumlu RS, Chen C, Jhaveri S, Tonegawa S (1994) Whiskerrelated neuronal patterns fail to develop in the trigeminal brainstem nuclei of NMDAR1 knockout mice. Cell 76:427-437.

Lohof AM, Delhaye-Bouchaud N, Mariani J (1996) Synapse elimination in the central nervous system: functional significance and cellular mechanisms. Rev Neurosci 7:85-101.

Mariani J, Changeux JP (1980) Multiple innervation of Purkinje cells by climbing fibers in the cerebellum of the adult staggerer mutant mouse. J Neurobiol 11:41-50.

Mariani J, Benoit P, Hoang MD, Thomson M-A, Delhaye-Bouchaud N (1990) Extent of multiple innervation of cerebellar Purkinje cells by climbing fibers in X-irradiated rats. Comparison of different schedules of irradiation during the first postnatal week. Dev Brain Res 57:63-70.

Mariani J, Crépel F, Mikoshiba K, Changeux JP, Sotelo C (1977) Anatomical, physiological and biochemical studies of the cerebellum from reeler mutant mouse. Philos Trans R Soc Lond B Biol Sci 281:93-97.

Masu M, Tanabe Y, Tsuchida K, Shigemoto R, Nakanishi S (1991) Sequence and expression of a metabotropic glutamate receptor. Nature 349:760-765.

Nakanishi S (1994) Metabotropic glutamate receptors: synaptic transmission, modulation, and plasticity. Neuron 13:1031-1037.

Nguyen QT, Lichtman JW (1996) Mechanism of synapse disassembly at the developing neuromuscular junction. Curr Opin Neurobiol 6:104-112.

O'Leary DDM, Ruff NL, Dyck RH (1994) Development, critical period plasticity, and adult reorganizations of mammalian somatosensory systems. Curr Opin Neurobiol 4:535-544.

Offermanns S, Hashimoto K, Watanabe M, Sun W, Kurihara H, Thompson RF, Inoue Y, Kano M, Simon MI (1997) Impaired motor coordination and persistent multiple climbing fiber innervation of cerebellar Purkinje cells in mice lacking G $\alpha \mathrm{q}$. Proc Natl Acad Sci USA 94:14089-14094.

Purves D, Lichtman JW (1980) Elimination of synapses in the developing nervous system. Science 210:153-157.

Rabacchi S, Bailly Y, Delhaye-Bouchaud N, Mariani J (1992) Involvement of the $N$-methyl-D-aspartate (NMDA) receptor in synapse elimination during cerebellar development. Science 256:1823-1825.

Schnupp JWH, King AJ, Smith AL, Thompson ID (1995) NMDAreceptor antagonists disrupt the formation of the auditory space map in the mammalian superior colliculus. J Neurosci 15:1516-1531.

Smith AL, Cordery PM, Thompson ID (1995) Manufacture and release characteristics of Elvax polymers containing glutamate receptor antagonists. J Neurosci Methods 60:211-217.

Takahashi T, Feldmeyer D, Suzuki N, Onodera K, Cull Candy SG, Sakimura K, Mishina M (1996) Functional correlation of NMDA receptor $\epsilon$ subunits expression with the properties of single-channel and synaptic currents in the developing cerebellum. J Neurosci $16: 4376-4382$.

Takechi H, Eilers J, Konnerth A (1998) A new class of synaptic response involving calcium release in dendritic spines. Nature 396:757-760.

Toki S, Watanabe M, Ichikawa R, Shirakawa T, Oguchi H, Inoue Y (1999) Early establishment of lesion-insensitive mature barrelettes corresponding to upper lip vibrissae in developing mice. Neurosci Res 33:9-15.

Vitalis T, Cases O, Callebert J, Launay JM, Price DJ, Seif I, Gaspar P (1998) Effects of monoamine oxidase A inhibition on barrel formation in the mouse somatosensory cortex: determination of a sensitive developmental period. J Comp Neurol 393:169-184.

Watanabe D, Inokawa H, Hashimoto K, Suzuki N, Kano M, Shigemoto R, Hirano T, Toyama K, Kaneko S, Yokoi M, Moriyoshi K, Suzuki M, Kobayashi K, Nagatsu T, Kreitman R, Pastan I, Nakanishi S (1998) Ablation of cerebellar Golgi cells disrupts synaptic integration involving GABA inhibition and NMDA receptor activation in motor coordination. Cell 95:17-27.

Watanabe M, Inoue Y, Sakimura K, Mishina M (1992) Developmental changes in distribution of NMDA receptor channel subunit mRNAs. NeuroReport 3:1138-1140.

Watanabe M, Mishina M, Inoue Y (1994) Distinct spatiotemporal expressions of five NMDA receptor channel subunit mRNAs in the cerebellum. J Comp Neurol 343:513-519.

Watase K, Hashimoto K, Kano M, Yamada K, Watanabe M, Inoue Y, Okuyama S, Sakagawa T, Ogawa S-I, Kawashima N, Hori S, Takimoto M, Wada K, Tanaka K (1998) Motor discoordination and increased susceptibility to cerebellar injury in GLAST mutant mice. Eur J Neurosci 10:976-988.

Weibel ER (1979) Stereological methods. Practical methods for biological morphology. London: Academic.

Woodward DJ, Hoffer BJ, Altman J (1974) Physiological and pharmacological properties of Purkinje cells in rat cerebellum degranulated by postnatal X-irradiation. J Neurobiol 5:283-304. 